\title{
急勾配トンネル水路による掃流砂輸送の研究
}

\section{STUDY ON THE BED LOAD TRANSPORT BY STEEP TUNNEL}

\author{
大本雄二 ${ }^{1} \cdot$ 宵田千裕 $^{2} \cdot$ 中山昭彦 ${ }^{3}$ \\ Yuji OMOTO, Chihiro YOIDA and Akihiko NAKAYAMA

\begin{abstract}
2 学生員 神戸大学大学院 自然科学研究科 建設学専攻（干657-8501 兵庫県神戸市灘区六甲台町 1-1)
\end{abstract} \\ 1 正会員 (株)ニュージェック 西日本事業本部 河川・海岸部（干542-0082 大阪市中央区島之内 1-20-19） \\ ${ }^{3}$ 正会員 ph. D. 神戸大学大学院教授 自然科学研究科地球環境科学専攻（同上）
}

\begin{abstract}
Sediment bypass system has been proposed as a countermeasure against sedimentation and turbid effluence that occur in reservoirs over long period of operation. In order to provide a guide fur reasonable design of such bypass tunnels, the flow with a movable sediment bed in a steep-sloped pipe has been studied both experimentally and numerically. The phenomenon observed in the experiment indicates that the flow is highly unsteady and non-uniform. An analysis method considering both of these aspects has been developed. The unsteadiness is not only local but it induces variations in the overall discharge. The energy loss due to rapidly varying bed shape is significant and a model for it has been formulated. The present analysis method is found to reproduce the main characteristics observed in the model experiments fairly well.
\end{abstract}

Key Words : bed variation analysis, steep tunnel, pipe flow

1.はじめに

国内外を問わず，ダム貯水池の堆砂問題とその対策は, ダム維持管理及び環境面から看過できない緊急かつ重 要な問題である ${ }^{1)}$. このような堆砂対策の一手法にバイ パス排砂システムが挙げられる.これはダム貯水池の末 端付近に取水口を, ダム下流に放水口を有する, 比較的 急勾配の水路を用いて, 洪水時に流下してくる土砂を, 貯水池を経ることなくダム下流に導くものである ${ }^{2)}$.

従前のバイパス排砂システムを対象とした研究とし ては, 旭ダム ${ }^{3)}$ を対象とした原田らの研究 ${ }^{4), 55,6)}$ がある. これらには，開水路で計画されているバイパス水路でも， 水路床への土砂堆積による管路流の形成やそれに伴う 負圧の発生等設計上有益な情報が含まれているが，これ らに対する評価は定性的なものにとどまっており，汎用 性のある定量評価はなされていない.

また，固液混相流分野におけるスラリー輸送の検討は， 基本的に流量をコントロールする被圧水平管が研究対 象で，急勾配水路を利用して自然に水を流下させること を念頭に置いたバイパス排砂の問題とは性質が異なる.
そこで筆者らは，バイパス排砂システム，特に掃流砂 を対象としたバイパス排砂システムの合理的な設計手 法の確立を目標として, 急勾配水路を用いた掃流砂輸送 を前提とした水理模型実験を実施するとともにバイパ ストンネル内の河床変動現象を適切に表現できる数値 シミュレーションモデルの構築を進めている.

すでに著者らは数值シミュレーションにおいて, 開水 路河床変動計算で用いられる手法を管路に適用して良 好な結果を得ている7),8) が，本論文では新たな実験デ一 夕を追加し，土砂が堆積した管路内で堆砂高が急変する 場合の損失特性や圧力・流量変動特性を明らかにすると ともに，管路を対象とした一次元非定常河床変動モデル を構築し，現象における非定常性について論じている.

\section{2. 実験概要 ${ }^{7), 8)}$}

実験装置を図-1 に示す.トンネル（アクリル樹脂製） は長さ $10 \mathrm{~m}$, 勾配 $1 / 33$, 断面形状は $5 \mathrm{~cm} \times 5 \mathrm{~cm}$ の幌型で, トンネル下流には平面規模 $90 \mathrm{~cm} \times 180 \mathrm{~cm}$ の水槽を置き, ポンプにより水を循環させる. 上流水槽の取水口部につ 
表-1 実験条件

\begin{tabular}{|c|c|c|c|c|}
\hline ケース名 & 流量 $(1 / \mathrm{s})$ & $\begin{array}{c}\text { 給砂量 } \\
(\mathrm{cc} / \mathrm{s})\end{array}$ & $\mathrm{t}_{\mathrm{s}}(\mathrm{s})$ & $\mathrm{t}_{\mathrm{c}}(\mathrm{s})$ \\
\hline Case1 & 2.35 & 125 & 40 & 約 $150^{* 2}$ \\
\hline Case2 & 2.35 & 190 & 27 & 約 $150^{* 2}$ \\
\hline Case3 & 2.35 & 125 & 20 & 90 \\
\hline Case4 & 2.65 & 125 & 40 & 約 $140^{* 2}$ \\
\hline Case5 & 2.35 & 125 & 60 & 約 $200^{* 2}$ \\
\hline
\end{tabular}

$* 1$ 空隙込みの量 $* 2$ 投入した土砂がトンネルから排出され,

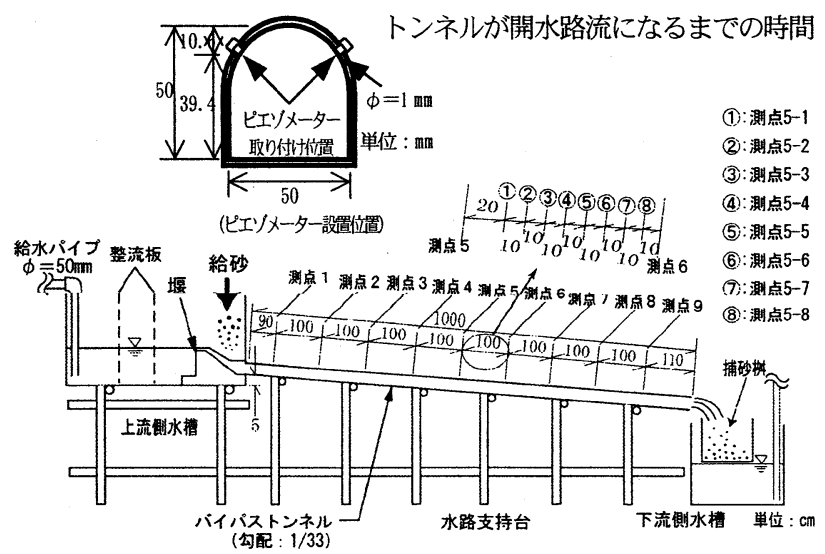

図-1実験装置

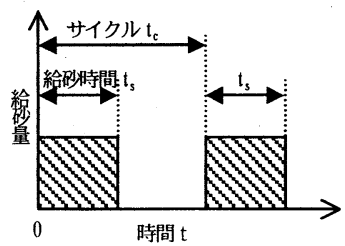

図-2 給砂条件

いては，投入土砂がタイムラグなくトンネルに流入する ように，取水口部前面に摺り鉢状の堰を設けた.

実験は, 一定流量を通水し (土砂投入前は開水路流), トンネル上流端からほぼ一様な粒径 $0.7 \mathrm{~mm}$ の砂を給砂し て, 複数の測点において, 圧力水頭（ピエゾメーター 十マノメーター), 堆砂高 (ビデオ), トンネル水位 (ビ デオ）を測定するとともに，下流端で流量（メスシリン ダーまたは三角堰）を計測した. 測点はN№.1，3，5，6， 7, 9 およびNo.5-1〜 5-8 の 14 測点である.

害験ケースを表-1 に示す。流量は土砂の投入により トンネル内が開水路流から管路流に遷移しやすい流量 を設定した. また, 給砂の条件は, 既往の研究において, 土砂の流入が間欠的になることが報告されており ${ }^{5)}$ ，そ れをイメージしたものとし, 給砂時間では連続的に土砂 を投入し，その投入土砂がバイパスから排出された後, 上流端からの空気の混入が認められた時に再び給砂を 行うようにした.（図-2）

\section{3.トンネル内圧力変動現象}

実験結果のうち, Case1 と 3 について, 上流水槽水位・ トンネル流量の時間変化，水路中間点付近 No.5 の圧力水 頭・堆砂高の時間変化を後述する計算值とともにそれぞ

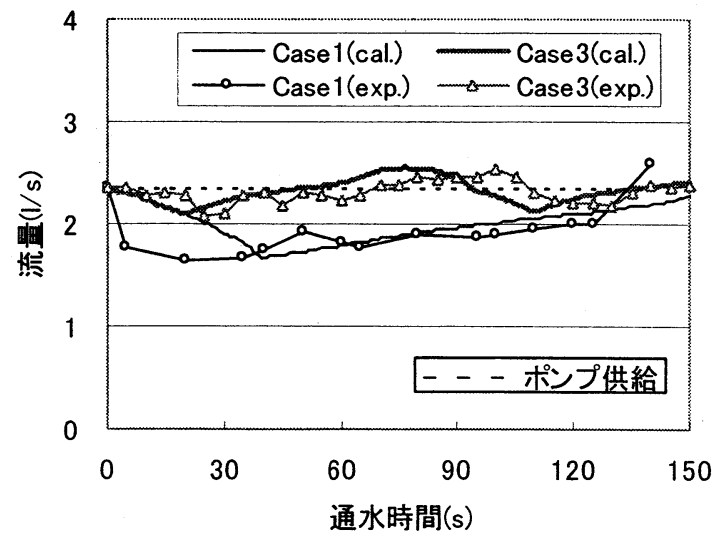

図－3 トンネル内流量の時間変化

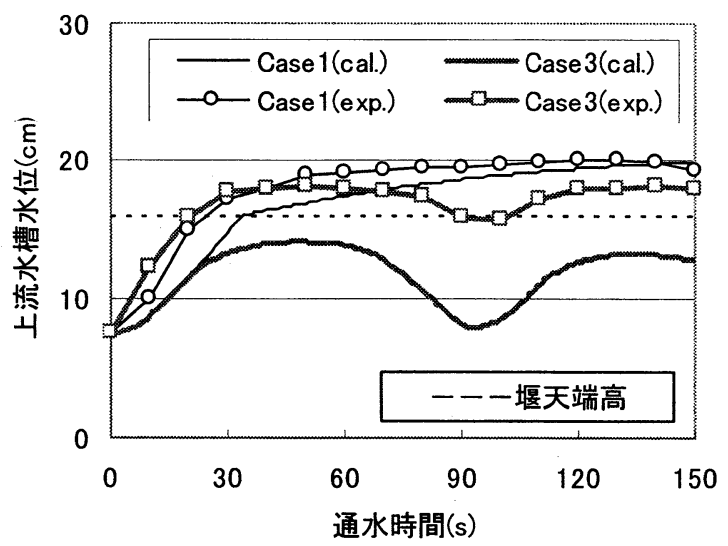

図-4 上流水槽内水位の時間変化
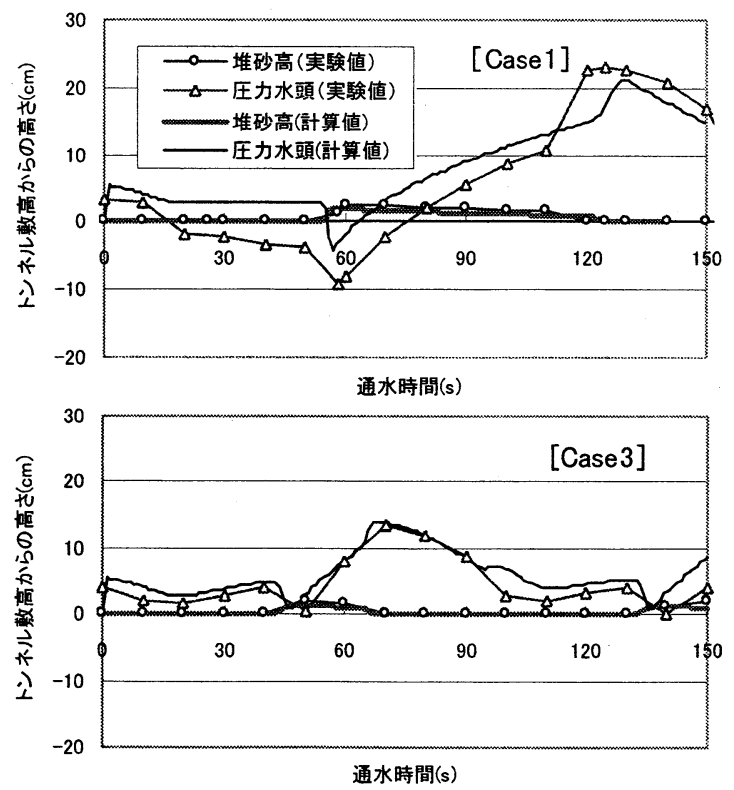

図-5 トンネル内圧力水頭, 堆砂高の時間変化（No.5）

れ図-3〜5 に示す. 動水勾配線, 堆砂高縦断形状の時間 変化は, 計算値とともに, 図-6，7に示されている.

開水路流状態の水路に土砂を投入するとトンネル内 に土砂が堆積し管路流へと遷移する．堆積土砂は時間と ともに部分堆積層流れを形成して流下し, やがて全量排 出される. その過程の中で, トンネル内の流量は時間的 に変動する (図-3) とともに, 上流端水槽水位も変動 (図 -4）する. さらにトンネル内では, 負圧を伴った圧力変 動現象が観測される（図-5）。 


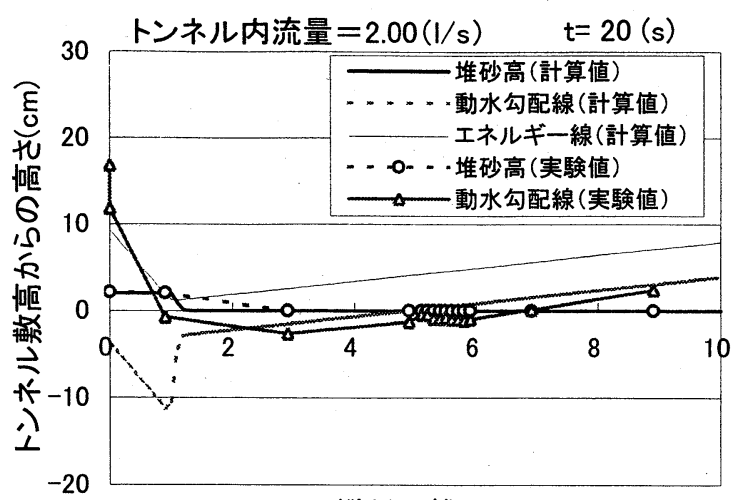

縦断距離(m)
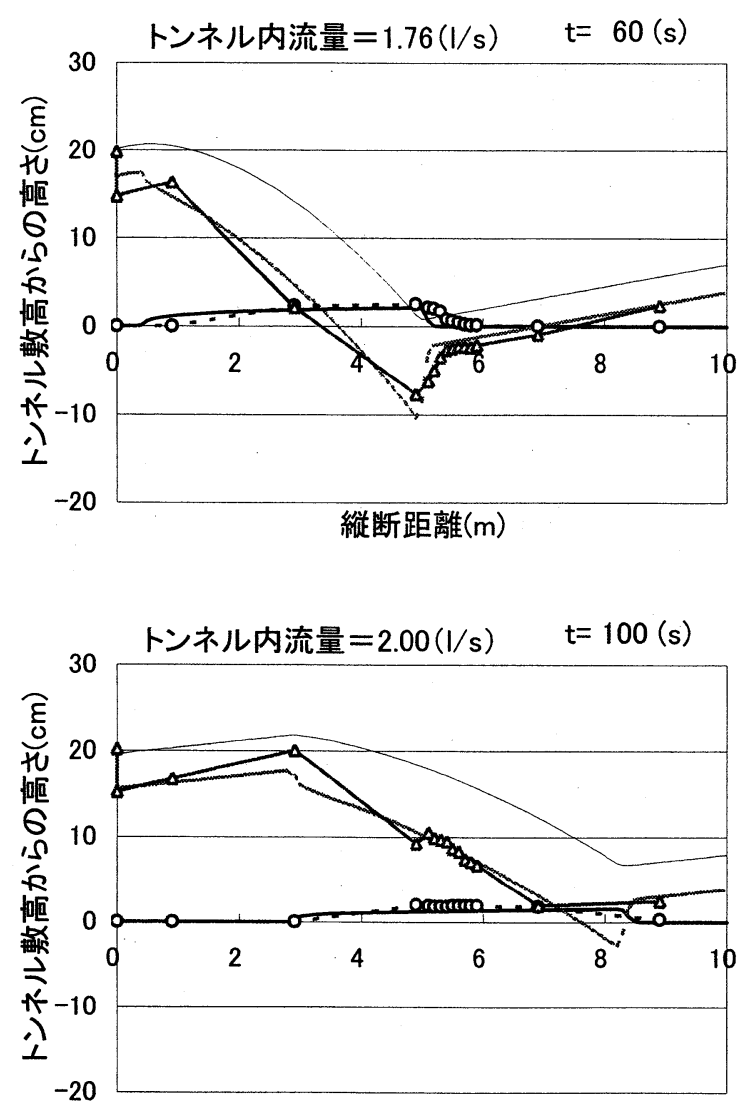

縦断距離 $(\mathrm{m})$

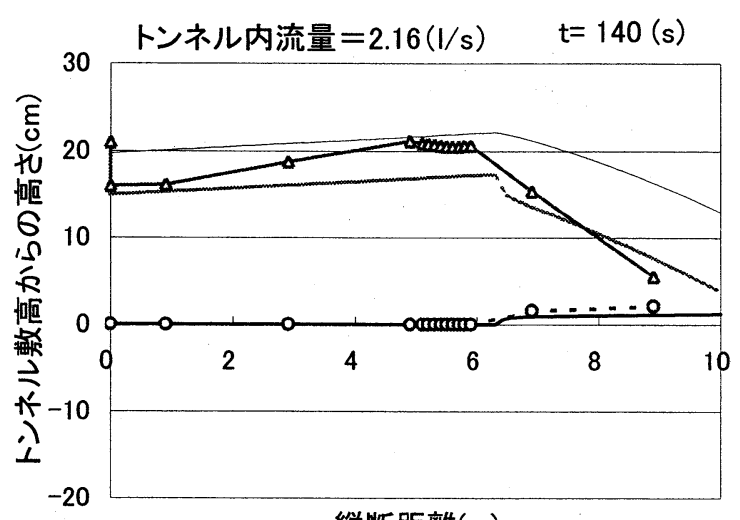

縦断距離 $(\mathrm{m})$

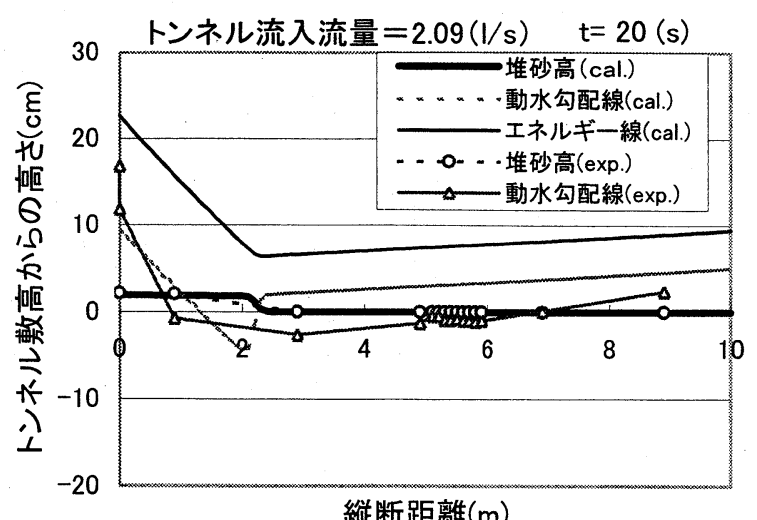

縱断距離 $(\mathrm{m})$
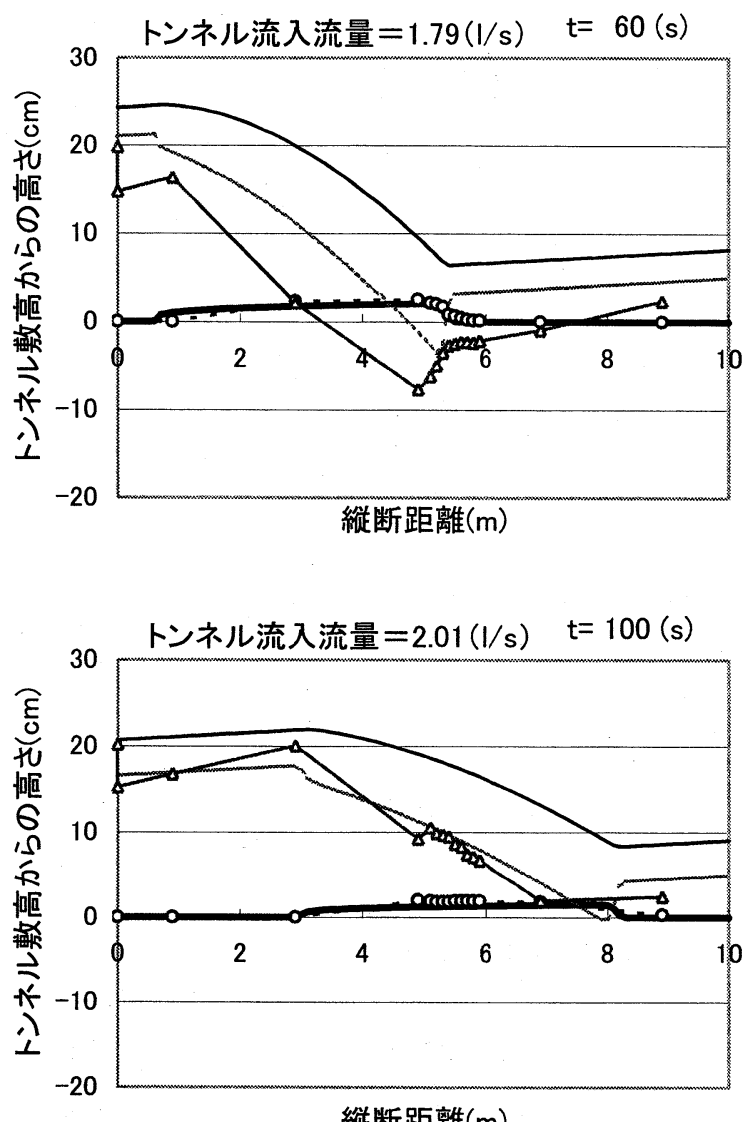

縦断距離(m)

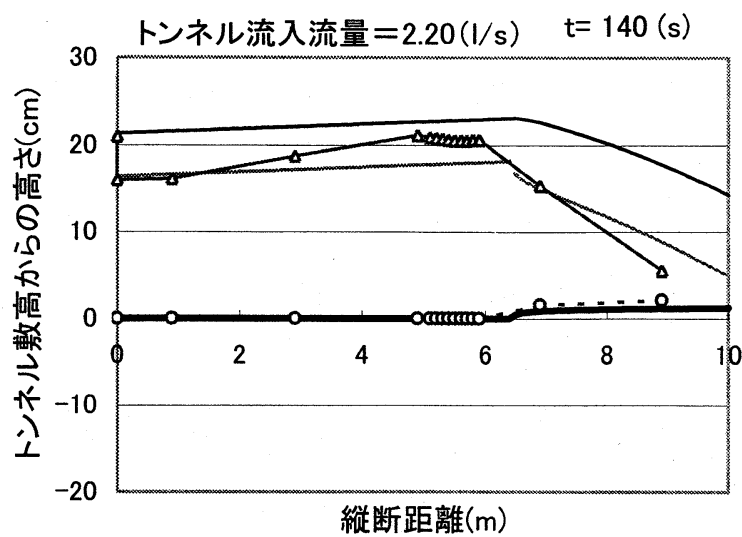

図-7 実験値と非定常計算值の比較 


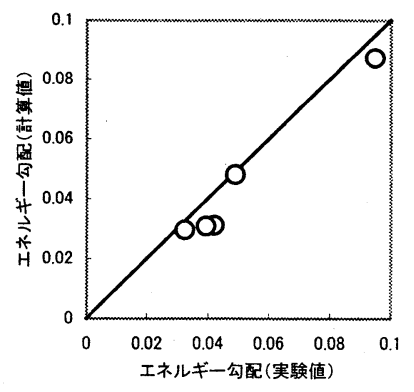

図-8 エネルギー勾配の比較

これらの時間変動は，2 ケースにおいて異なるのは給 砂条件のみであることから，土砂の動きと密接に関わっ ていることがうかがえる.すすなおトンネル内の土砂流 入により管内の抵抗が増大し（図-6)，トンネル流量が 減少する (図-3) ために上流水槽水位は上昇する (図-4). 給砂が終了（Case1 で 40s 後）すると管内抵抗は徐々に 減少し，トンネル流入流量が増大に転じる. やがて土砂 が排出されるに至って，上流水槽水位に見合った流量が 流下し, 実験の初期状態に復する。その現象の中で土砂 堆積部分のエネルギー損失が大きいため堆砂の先端付 近で負圧が発生すると解釈される（図-6）。このような 圧力変動現象は原田ら ${ }^{5)}$ も見いだしているが，トンネル 流量の変動については論じられておらず，今回の実験か ら，土砂が堆積していなければ十分開水路流で流せる流 量 (表-1 に示した流量) でも管路流の状態となり，初期 設定の $20 \%$ 程度の流量減少が起こりうることが明らかに なった.

\section{4. 堆砂高急変部のエネルギー損失特性}

\section{（1）一様な堆砂高部のエネルギー勾配}

土砂准積層を伴った管路流の抵抗則，エネルギ一損头 特性については，その流動形態とともに種々の研究が見 られ ${ }^{9214)}$ ，これらは管の縦断方向で堆積層の厚さが一 様な場合のエネルギ一勾配について論じられている.

ここではまず, 今回の実験で得られたほぼ一様な堆砂 高を有する部分でのエネルギー勾配と既往検討による それを比較する. ここで計算值は後述するように径深分 割法 ${ }^{12)}$ に従った. その結果を図-8 に示すが，両者に良 好な一致がみられるといえよう。

\section{（2）堆砂高急変部のエネルギー損失}

実験でみられた堆砂高が急変する部分でのエネルギ 一損失について図-9 のように急拡損失 $\Delta h$ を定義した場 合の急拡損失係数と, 固定床を前提とした管路の急抁損 失係数を比較した結果を図-10 に，同様に定義した急縮 損失係数と固定床のそれを比較したものを図-11 にそれ ぞれ示す．ここで固定床の急拡，急縮損失係数は堆砂の ある部分を細管, 堆砂のない部分を太管とみなして次式

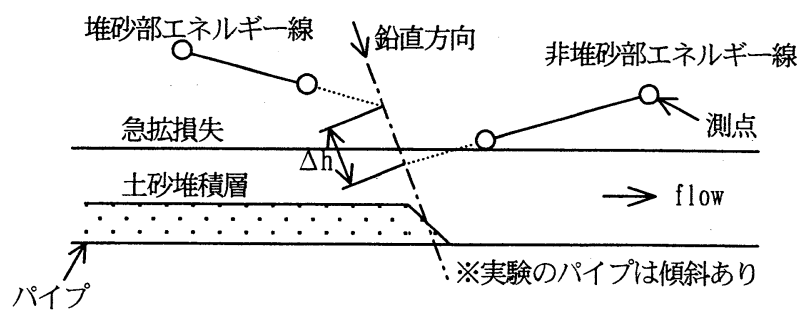

図-9 急昖損失の定義

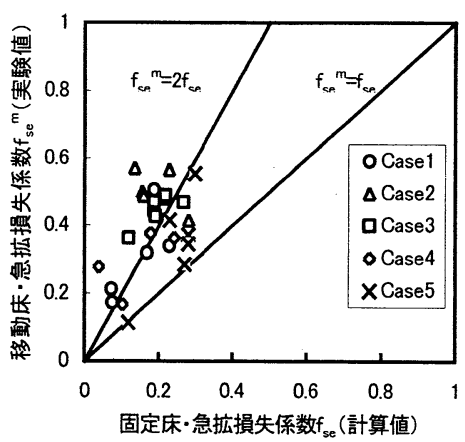

図-10 急抎損失係数の比較

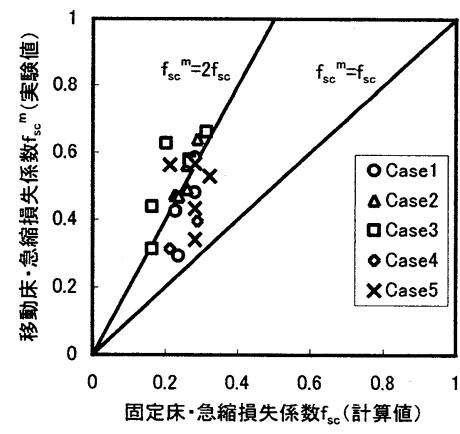

図-11 急縮損失係数の比較

により算定した.

$$
\begin{aligned}
& f_{s e}=\left(1-\frac{A_{1}}{A_{2}}\right)^{2} \quad \text { (急拡) } \\
& f_{s c}=\left(\frac{1}{C_{c}}-1\right)^{2} \quad \text { (急縮) }
\end{aligned}
$$

ここに $f_{s e}$ : 固定床の急抎損失係数, $A_{1}$ : 細管 (上流側) の径, $A_{2}$ : 太管 (下流側) の径, $f_{s c}$ : 固定床の急縮損失 係数, $C_{c}$ : 縮流係数である.

移動床の急変部損失係数は実測の $\Delta h$ を用いて次式に よった.

$$
f_{s e, s c}^{m}=\Delta h /\left(v^{2} / 2 g\right)
$$

ここに $f_{s e}^{m}$ : 移動床の急挔損失俰数, $f_{s c}^{m}$ : 移動床の急縮 損失係数, $v$ : 断面平均流速 (急拡時上流側, 急縮時下流 側), $g$ : 重力加速度である.

今回の実験現象は, 固定床管路流の異径管の接合ほど の急激な断面変化ではないが, かなり大きな損失が発生 していることがうかがえ，その程度は損失係数で評価す るとおおよそ固定床の 2 倍である. 


\section{5. 数值シミュレーション}

\section{（1）数值解析手法}

筆者らは, 急勾配管路流に開水路流で用いられる河床 変動計算を適用し, ある程度の再現性, 有用性があるこ とを示した. ${ }^{8)}$ その際の解析手法は, ある時間, ある場 所の土砂堆積高が既知として流れを一次元定常流で計 算し, そのとき得られた水理量で流砂量を算定して, 河 床変動量を計算するというものである. 各断面の水理量 の算定にあたっては，断面を砂礫面が支配する領域と管 壁が支配する領域として分割するモデル（径深分割法） 12）を採用した.

ここでは, 今後のバイパス排砂水路の合理的設計手法 の確立を念頭に置き, 計算精度の向上, 汎用化を目指し, 流れに対して非定常性を考慮したモデルを構築した. た だし，実験現象は開水路流 $\rightarrow$ 管路流 $\rightarrow$ 開水路流之遷移す るが，数值解析では，下流端での水位を管路頂高さで固 定し，管路流を前提とした計算を行った.

\section{（2）基礎方程式と計算方法}

流れの計算は，一次元非定常管路流であり，質量保存 式，運動量保存式は以下のように表される.

$$
\begin{gathered}
\frac{\partial h}{\partial t}+v \frac{\partial h}{\partial x}+\frac{a^{2}}{g} \cdot \frac{\partial v}{\partial x}=0 \\
g \frac{\partial h}{\partial x}+\frac{\partial v}{\partial t}+v \frac{\partial v}{\partial x}+g\left(s_{f}-s_{o}\right)=0
\end{gathered}
$$

ここに $h$ :管底基準のピエゾ水頭, $v$ : 断面平均流速, $a$ : 圧力の伝幡速度, $g$ : 重力加速度, $s_{f}$ : 摩擦勾配, $s_{o}$ : 管 勾配, $t$ : 時間, $x$ : 流下方向距離である.

流れについては，(4)，(5)を連立させて特性曲線法を 用いて解いた. また，摩擦勾配の算定は径深分割法 ${ }^{12}$

(図-12）によるものとし，以下の (6)，(7)，(8)式で評 価した.

$$
\begin{gathered}
R_{p} S_{p}+R_{s} S_{s}=A \text { (断面分割式) } \\
\frac{v}{u_{* p}}=3.0+5.75 \log _{10}\left(\frac{u_{*_{p}} R_{p}}{v}\right), u_{*_{p}}=\sqrt{g R_{p} I} \\
\left(A_{p} \text { 領域の流速の式 }\right) \\
\frac{v}{u_{*_{s}}}=6.0+5.75 \log _{10}\left(\frac{R_{s}}{k_{s}}\right), u_{*_{s}}=\sqrt{g R_{s} I} \\
\left(A_{s} \text { 領域の流速の式 }\right)
\end{gathered}
$$

ここに $A$ : 堆砂高を考慮した流積, $v$ : 断面平均流速,

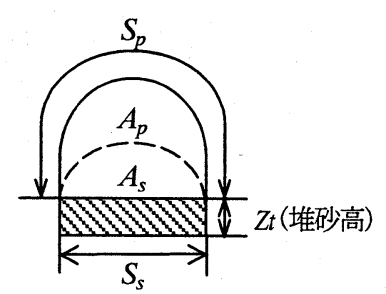

図-12 断面分割説明図

$R_{p} \cdot R_{s}:$ それぞれ $A_{p} \cdot A_{s}$ 領域の径深, $S_{p} \cdot S_{s}:$ それぞれ $A_{p} \cdot$ $A_{s}$ 領域の潤辺, $k_{s}$ : 相当粗度 (粒径使用), $v$ : 動粘性係 数, $I:$ エネルギー勾配である.

これらの水理量は，ある時間での河床高が既知である とし， $\Delta t$ 秒間の河床変動量が流れに与える影響は無視 している. 河床高の算定は, 河床高を固定した水理量の 算定結果に対し, 以下の流砂の連続式, 流砂量式 (芦田・ 道上式）により行った。

$$
\begin{gathered}
\frac{\partial Z_{s}}{\partial t}+\frac{1}{1-\lambda} \cdot \frac{1}{B} \cdot \frac{\partial}{\partial x}\left(q_{B} \cdot B\right)=0 \\
\frac{q_{B}}{\sqrt{(\sigma / \rho-1) g d^{3}}}=17 \tau_{*_{s}}^{3 / 2}\left(1-\frac{\tau_{*_{c}}}{\tau_{*_{s}}}\right)\left(1-\frac{u_{*_{c}}}{u_{*_{s}}}\right)
\end{gathered}
$$

ここに $Z_{s}$ : 河床高, $t$ : 時間, $\lambda$ : 空隙率, $B$ : 掃流幅, $x$ : 流下方向距離, $q_{B}$ : 単位幅掃流砂量, $\sigma$ : 砂粒子の密度, $\rho$ : 水の密度, $d$ : 粒径, $\tau_{*_{c}}$ : 無次元限界掃流力, $\tau_{*_{\mathrm{S}}}$ : 無次元掃流力, $u_{*_{c}}$ : 限界摩擦速度, $u_{*_{s}}$ : 摩擦速度 (添 え字 $s$ は堆砂部が支配する領域の意）である.

これらの諸式に基づき流れと河床変動を交互に算定 することにより, エネルギー高, 河床高を順次求めてい った. なお, 計算時間間隔は $\Delta t=0.05$ 秒, 断面間距離 は $\Delta x=0.1 \mathrm{~m}$ としている. また, 本来, 図-10,11 の結果 も考慮した解析とすべきところであるが，次の理由によ り今回は扱わないも0とした. すなわち，図-6 の定常計 算は，管全体の損失量が実験值から既知であることを前 提に流量を決定しており，そのとき断面変化による損失 を考慮しておらず，ここでは定常計算と非定常計算の比 較を目的としているため, 非定常計算でも断面変化によ る局所損失は扱わないほうが比較が容易であると考え たためである.

\section{（3）上流端の処理}

実験で観測された現象を，非定常流で計算するにあた っては, 時間的に変化するトンネル流入流量を適切に設 定する必要がある.ここでは, トンネル流入流量の時間 変化は, トンネル部のエネルギーの総損失量の時間変化, 上流水槽の水位の変化によって規定されるものと考え, 以下の考え方により算定した.

まず, $t=t_{1}$ および $t=t_{1}+\Delta t=t_{2}$ における河床高が既知 である状態に対して, $t=t_{1}$ および $t=t_{2}$ での既知流量 $\mathrm{Q}_{1}$, $Q_{2}$ を用いて, 損失量 $h_{\ell 1}, h_{\ell 2}$ を算定し, 次に $t=t_{1}$ の河床 
高に対して $h_{\ell 2}$ となる流量 $Q_{2}$ 'を繰り返し計算により求 める. その流量 $Q_{2}$ 'に対して, 上流水槽水位 $H_{s}$ の変 化割合, $\sqrt{d H s / d t}$ で $Q_{2}$ 'を増減させ, この量を $t=t_{2}$ で の流入流量とした. 上流水槽水位は, ポンプからの供給 流量 $Q_{u p}$ とトンネル流入 $Q_{i n}$ の収支として次式により算定 した.

$$
\begin{gathered}
H_{s}=f(V) \\
V=V_{O}+\int Q_{u p}(t) d t-\int Q_{i n}(t) d t
\end{gathered}
$$

ここに $V$ : 上流水槽に貯まった水の体積, $V_{0}: t=0$ におけ る上流水槽に貯まった水の体積である.

\section{(4) 計算結果}

図-6に流れの計算を定常流とした場合の計算結果 ${ }^{8)}$ を, 図-7に流れの計算に非定常性を考慮した場合の計算結 果をそれぞれ示す．定常流の計算は, 実験における総損 失量を既知, 流量 $Q$ を未知として, 損失量に見合う流量 を算定した上で計算している. 非定常流計算では, 前述 の上流端の処理により, トンネル流入流量は, 実験で得 られた損失量とは無関係に決定されている. トンネル流 入量の結果は図-3に示されているが、Case3 では流量を 検定水槽で計測しており計算との時間ずれがある点に 留意されたい. 両図を比較すると, 流量条件が異なるた め，一概にはいえないが，非定常性を考慮した検討で， 特に計算精度が向上しているとはいえない結果となつ た.これは換言すれば，今回の管路流の現象は，トンネ ル流入流量さえ適切に評価できれば, 特に非定常性を考 慮する必要はないともいえる. ただし，これらは解析に おいては管路流を前提にしていて, 実際の現象は開水路 流からスタートし, 土砂の堆積が管路流を惹起している という点を全く考慮していないため, その間の非定常性 については検討の余地を残している.

\section{6. おわりに}

本研究から得られた主要な知見は以下のようである. （1）管路内において, 流砂を伴った土砂堆積層が存在し, その厚さが急激に変化する部分では，異径管の接続部な どで適用される固定床の断面急変部損失より, 大きな損 失が発生することを実験的に明らかにした.

（2）土砂流入によって圧力変動が生じている場合には, トンネル内流量も変動していることを示した.

（3）急勾配管路における河床変動現象は，流れに対する 一次元非定常流ないしは流量変化を考慮した一次元定 常流と河床変動計算を交互に繰り返す解析手法により 概ね表現できる.
今後は, 急拡, 急縮の損失も考虑した管・開水路が混 在する流れ場を対象とした非定常流のトンネル内河床 変動モデルを構築し, バイパス排砂システムの合理的設 計に対する基礎資料を提示していく予定である.

謝辞 : 本研究を実施するにあたり, 害験等に御協力頂い た神戸大学 細川茂雄助教授, 藤田一郎助教授, 市成準 一技官, 工学部学生諸氏, ならびに侏旧本工業試験所 谷 美智成氏に謝意を表します。

\section{参考文献}

1) Suzanne Pritchard : Overloaded, International Water Power \& Dam Construction, PP. 18-22, 2002.

2）寺田昌史, 原田稔, 芦田和男 : 貯水池のバイパス排砂シス テムの計画について, 土木学会第 50 回年次学術講演会概 要集, 2-A, PP. 418-419, 1995.

3）原田稔，森本浩, 小久保鉄也：バイパス排砂システムの運 用実績己効果, 大ダム No.173, PP. 38-45， 2000.

4) 原田稔, 寺田昌史, 出野尚, 大本雄二: 貯水池のバイパス 排砂システムによる掃流砂排出システムに関する実験的 研究, 水工学論文集 Vol.40, PP. 813-818, 1996.

5）原田稳，小久保鉄也，出野尚: 貯水池のバイパス排砂シス テムにおけるトンネル内土砂水理特性, 土木学会論文集, No.600/II-44, PP. 69-84, 1998.

6）原田稔: 貯水池のバイパス排砂システムに関する研究, 京 都大学学位論文, 1998.

7）大本雄二, 宵田千裕, 中山昭彦：バイパス排砂システムの 圧力変動特性, 土木学会第 57 回年次学術講演会概要集 II -166, PP. 331-332, 2002.

8）大本雄二, 宵田千裕, 中山昭彦: 開水路河床変動解析手法 の移動床急勾配管路流への適用性，応用力学論文集 Vol.5, PP. 649-656, 2002.

9）野田佳六: 土砂の管路輸送, 第 22 回水工学に関する夏期研 修会講義集 A-3-1 16, 1986.

10）野田佳六, 高橋弘, 川島俊夫 : 堆積層をともなう流れにお ける圧力損失一水平管内固液二相流における粒子群の挙 動に関する研究 (第 3 報) 一, 日本鉱業会誌 Vol.101, No. 1173, PP. 363-368, 1985.

11）高橋弘, 野田佳六, 益山忠: 瀷動層をともなう流れにおけ る圧力損失一水平管内固液二相流における粒子群の挙動 に関する研究 (第 5 報) 一, 日本鉱業会誌 V01.103, No. 1188, PP. 101-107, 1987.

12）芦田和男, 江頭進治, 中島智彦: 水平管路における土砂輸 送形態之砂流機構, 京大防災研究所年報 第 31 号 B-2, PP. 489-506, 1988.

13）辻本哲郎，蔵重俊夫，北村忠紀，岡田敏治 : 堆積層を伴う 円管内の掃流砂, 水工学論文集 Vol. 38, PP. 653-658, 1994.

14）栗原崇, 鈴木幸一, 池辺健作 : 水平管路における摺動層流 れの実験，水工学論文集 Vol. 40, PP. 831-836, 1996.

(2002. 9. 30受付) 